Journal of Geoscience, Engineering, Environment, and Technology Vol 02 No 022017

\title{
Metamorphic rock-hosted orogenic gold deposit style at Bombana (Southeast Sulawesi) and Buru Island (Maluku): Their key features and significances for gold exploration in Eastern Indonesia
}

\author{
Arifudin Idrus ${ }^{1 *}$, , Sukmandaru Prihatmoko ${ }^{2}$, Ernowo Harjanto ${ }^{3}$, Franz Michael \\ Meyer $^{4}$, Irzal Nur ${ }^{5}$, Wahyu Widodo ${ }^{3} \&$ Lia Novelia Agung ${ }^{3}$ \\ ${ }^{1}$ Department of Geological Engineering, Gadjah Mada University, Yogyakarta \\ ${ }^{2}$ PT. SJR-Pama Group, Jakarta. \\ ${ }^{3}$ Geological Agency of Indonesia, Bandung \\ ${ }^{4}$ Department of Mineralogy and Economic Geology, RWTH Aachen University, Germany \\ ${ }^{5}$ Department of Geological Engineering, Hasanuddin University, Makassar.
}

\author{
* Corresponding author : arifidrus@ugm.ac.id \\ Tel.: +62-2754-513668 \\ Received: May 2, 2017. Revised : May 25, 2017, Accepted: May 31, 2017, Published: 1 June 2017 \\ DOI: 10.24273 /jgeet.2017.2.2.291
}

\section{Abstract}

In Indonesia, gold is commonly mined from epithermal-, porphyry-, and skarn-type deposits that are commonly found in volcanic belts along island arcs or active continental margin settings. Numerous gold prospects, however, were recently discovered in association with metamorphic rocks. This paper focuses on metamorphic rock-hosted gold mineralization in Eastern Indonesia, in particular the Bombana (SE Sulawesi) and Buru Island (Maluku) prospects. At Bombana, gold-bearing quartz-veins are hosted by the Pompangeo metamorphic complex. Sheared, segmented veins vary in thickness from $2 \mathrm{~cm}$ to $2 \mathrm{~m}$. Gold is mainly present in the form of 'free gold' among silicate minerals and closely related to cinnabar, stibnite, tripuhyite, and in places, minor arsenopyrite. The gold distribution is erratic, however, ranging from below detection limit up to $134 \mathrm{~g} / \mathrm{t}$. At least three generations of veins are identified. The first is parallel to the foliation, the second crosscuts the first generation of veins as well as the foliation, and the late-stage laminated deformed quartz-calcite vein represents the third mineralization stage. The early veins are mostly massive to crystalline, occasionally brecciated, and sigmoidal, whereas the second-stage veins are narrower than the first ones and less subjected to brecciation. Gold grades in the second- and third-stage veins are on average higher than that in the earlier veins. Microthermometric and Raman spectrometric studies of fluid inclusions indicate abundant $\mathrm{H} 2 \mathrm{O}-\mathrm{NaCl}$ and minor $\mathrm{H} 2 \mathrm{O}-\mathrm{NaCl}-\mathrm{CO} 2$ fluids. Homogenization temperatures and salinities vary from 114 to $283^{\circ} \mathrm{C}$ and 0.35 to $9.08 \mathrm{wt} . \% \mathrm{NaCl}$ eq., respectively. Crush-leach analysis of fluid inclusions suggests that the halogen fluid chemistry is not identical to sea water, magmatic or epithermal related fluids, but tends to be similar to fluids in mesothermal-type gold deposits. In Buru Island (Gunung Botak and Gogorea prospects), two distinct generations of quartz veins are identified. Early quartz veins are segmented, sigmoidal discontinuous and parallel to the foliation of the host rock. This generation of quartz veins is characterized by crystalline relatively clear quartz, and weakly mineralized with low sulfide and gold contents. The second type of quartz veins occurs within the 'mineralized zone' of about $100 \mathrm{~m}$ in width and $-1,000 \mathrm{~m}$ in length. Gold mineralization is intensely overprinted by argillic alteration. The mineralization-alteration zone is probably parallel to the mica schist foliation and strongly controlled by N-S or NE-SW-trending structures. Gold-bearing quartz veins are characterized by banded texture particularly following host rock foliation and sulphide banding, brecciated and rare bladed-like texture. Alteration types consist of propylitic (chlorite, calcite, sericite), argillic and carbonation represented by graphite banding and carbon flakes. Ore mineral comprises pyrite, native gold, pyrrhotite, and arsenopyrite. Cinnabar and stibnite are present in association with gold. Ore chemistry indicates that 11 out of 15 samples yielded more than $1 \mathrm{~g} / \mathrm{t} \mathrm{Au}$, in which 6 of them graded in excess of $3 \mathrm{~g} / \mathrm{t}$ Au. All high-grade samples are composed of limonite or partly contain limonitic material. This suggests the process of supergene enrichment. Interestingly, most of the high-grade samples contain also high concentrations of As (up to 991ppm), Sb (up to 885ppm), and $\mathrm{Hg}$ (up to 75ppm). Fluid inclusions in both quartz vein types consist of 4 phases including L-rich, V-rich, L-V-rich and L1-L2-V (CO2)-rich phases. The mineralizing hydrothermal fluid typically is $\mathrm{CO} 2$-rich, of moderate temperature $\left(300-400^{\circ} \mathrm{C}\right)$, and low salinity $(0.36$ to $0.54 \mathrm{wt} . \% \mathrm{NaCl}$ eq). Based on those key features, gold mineralization in Bombana and Buru Island tends to meet the characteristics of orogenic, mesothermal types of gold deposit. Metamorphic rock-hosted gold deposits could represent the new targets for gold exploration particularly in Eastern Indonesia.

Keywords: Characteristics, Orogenic Gold, Bombana, Buru Island, Indonesia. 


\section{Introduction}

\subsection{Background study}

During last few decades, in Indonesia gold has mostly been extracted from volcanic-hosted hydrothermal deposits, including LS epithermal type e.g. Pongkor in West Java, Gosowong in Halmahera Island, HS epithermal type e.g. Martabe (Sumatra), Cijulang (Jawa) and Lanut, Doup (Sulawesi), skarn type e.g. Erstberg, Big Gossan, Kucing Liar, Deep Ore Zone (DOZ) in Papua and porphyry type e.g. in Grasberg (Papua), Batu Hijau (Sumbawa Island) and Tombulilato (Sulawesi). However, currently gold is not only found in volcanic terrain, but also many discoveries of placer (secondary) and primary gold mineralization are genetically occurred in association with metamorphic rocks, for instance, Awak Mas mesothermal (Querubin\& Walters, 2011), Poboya LS-epithermal (Wajdi et al., 2011) and Rampi (North Luwu) (Idrus et al., 2016). Gold-bearing quartz veins are also recognized in Derewo metamorphic belt at northern and northwestern part of Central Range Papua. Some exploration reports categorized the Derewo metamorphic-related quartz veins into mesothermal gold deposit type. In Bombana (SE Sulawesi) (Fig.1), gold deposit is hosted by metamorphic rocks of the Pompangeo Metamorphic Complex (M tpm). In addition, in this area placer gold is also being mined from MioPliocene sediments of Langkowala Formation. This placer gold is interpreted to be sourced from primary gold deposit hosted by the Mtpm. Similarly, gold deposit is also discovered in Buru Island (Gunung Botak and Gogorea), Maluku (Fig.1), which is hosted by Wahlua Metamorphic Complex (Pzw). Both Mtpm and Pzw are of Upper Carboniferous until Lower Permian age (Simanjuntak et al. 1993; Tjokrosapoetro et al., 1993). The genetic type of the Bombana and Buru Island gold mineralization are still debatable. This paper is aimed to discuss some key characteristics of the primary deposit including host rock petrology, quartz vein texture and structure, hydrothermal alteration, ore mineral and chemistry and mineralizing hydrothermal fluid properties. It is expected that the result would be important for a better understanding of the genesis of thegold mineralization, and would be useful in designing future exploration strategy for gold deposits in Indonesia.

\section{Research Methods}

This study has been carried out through several approaches including desk study, fieldwork and sampling for laboratory analyses. There is no previous detailed study and publication that was focused specifically on the primary gold mineralisation both in Bombana and Buru Island. Therefore, during the desk study only few literatures related to Bombana placer gold can be reviewed, e.g. Makkawaru \& Kamrullah (2009) and Surono \& Tang (2009). Quartz vein samples were taken, and geochemically analyzed by Fire Assay combined with AAS, gravimetric fire assay (GA), cold vapour AAS (CV) conducted in ITS laboratory, Jakarta and AAS laboratory of Georesources Research Center, Bandung. Data of quartz vein assays from Prihatmoko et al, (2010) that were taken adjacent to the studied area are also incorporated into discussion. A single ICP-MS analysis from Buru Island sample was done by Prof. Victor Okrugin in Kamchatka University, Russia. Mineral chemistry of stibnite as a diagnostic ore mineral was also analyzed using EPMA (Electron Probe Micro Analyzer) at RWTH Aachen University. Fluid inclusion in various generations of quartz veins was micro thermometrically analyzed by LINKAM THMS600 heating and freezing stage at RWTH Aachen University, Germany and Geotechnology Research Centre, LIPI, Bandung. Raman spectrometry and crush-leach analysis of fluid inclusion was done at Georesources Research Center, Bandung and Leoben University, Austria, respectively.

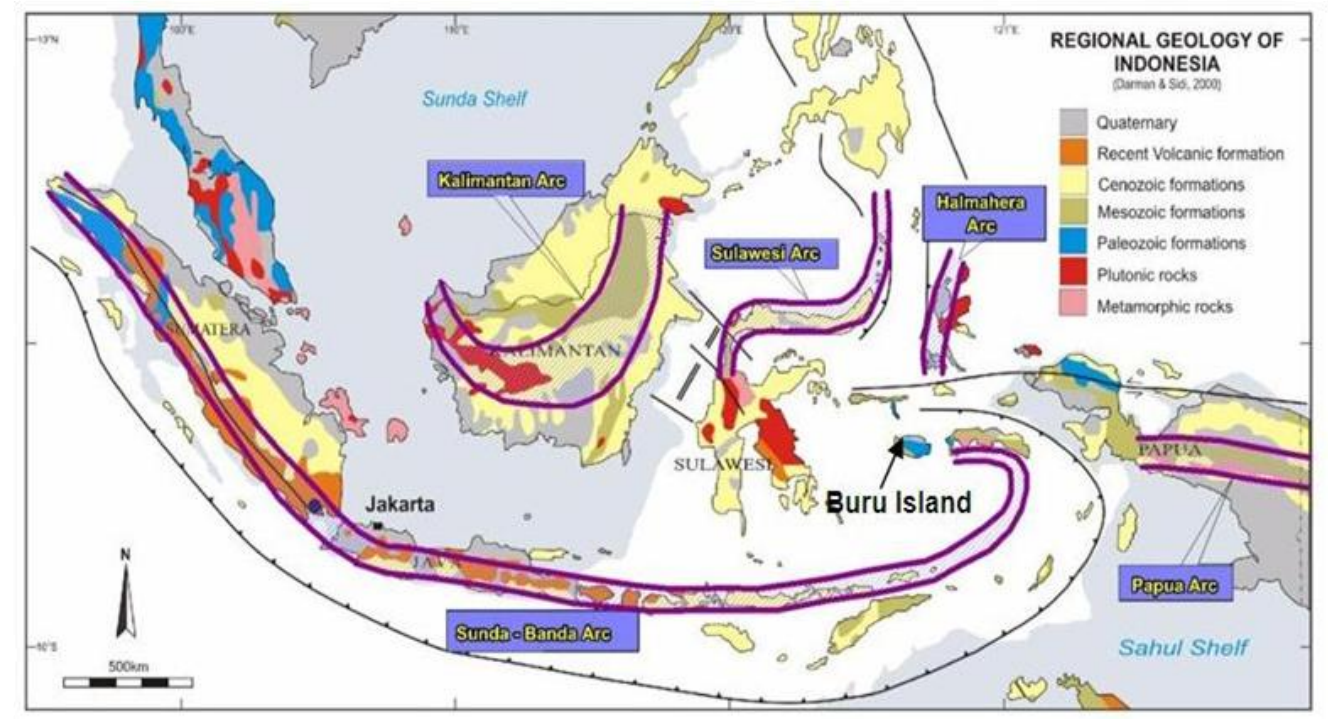

Fig. 1 Location map of study areas i.e. Bombana (SE Sulawesi) and Buru Island (Moluccas) 


\section{Result and Discussion}

\subsection{Deposit Geology}

\section{Bombana Gold Deposit}

The area is occupied by Mio-Pliocene Langkowala Formation (Tmls) consisting of conglomerate and sandstone. The Langkowala Formation is unconformably underlain by Mesozoic metasediments and metamorphic rocks (Pompangeo Complex, Mtpm) (Simanjuntak et al., 1993). The metamorphic rocks consist of mica schist, quartzite, glaucophane schist and chert. The metasediments and metamorphic rocks occupy the Mendoke and Rumbia Mountains. Mica schist and metasediments particularly meta-sandstone and marble are commonly characterized by the presence of quartz veins/veinlets with various width up to 2 meters, containing gold in some places. Interpretative E-W-trending faults, which are relatively parallel to the foliation attitude of the metamorphic rocks apparently acts as mineralization-hosting shear zones that formed first generation of quartz veins/reefs in the area. The
NE trending faults are thought to be the main control of the formation of second generation of quartz veins (that cross-cut the foliations). The regional geology of Bombana (including Langkowala) and local geological map are shown in Fig. 2. As explained previously, the quartz veins are predominantly hosted by metamorphic rocks particularly mica schist. Mica schist is the predominant rock type in the area. Some outcrops at Wumbubangka shows a general foliation of $\mathrm{N}$ $300 \mathrm{oE} / 60$ o. Some foliation variations e.g. N80E/6070으 was reported (Prihatmoko et al., 2010). Petrographic study of the mica schist indicates that the rock is abundantly composed of muscovite, chlorite and quartz with a small amount of actinolite, albite, epidote, sericite and opaque minerals. Based on those mineral assemblages, it is considered that the metamorphic rock is categorized into green schist facies (cf.Yardley, 1989). It is also important to note that the majority of the metamorphogenic-related gold deposits worldwide are hosted by greenschist facies (GebreMariam et al., 1995).

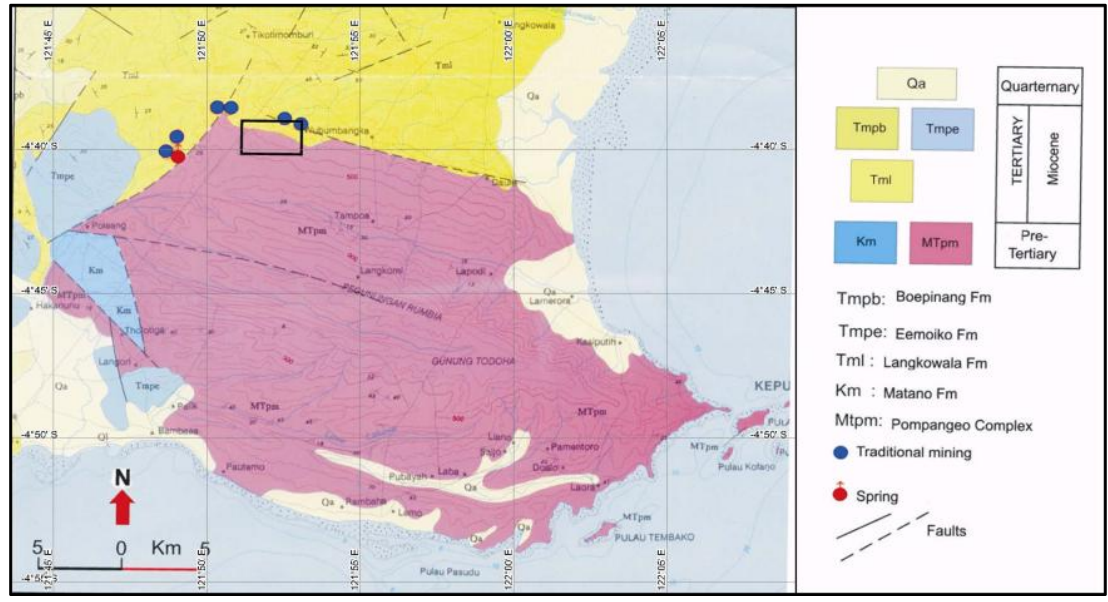

Fig. 2 Geological map of Langkowala area occupied by Langkowala Formation (Tml) and unconformably overlain Paleozoic metamorphic rocks (Pompangeo Complex; Mtpm) in the south (Wumbubangka and Rumbia mountain range) (Base map from Simandjuntak et al., 1993). Squared area indicates the location area of this study.

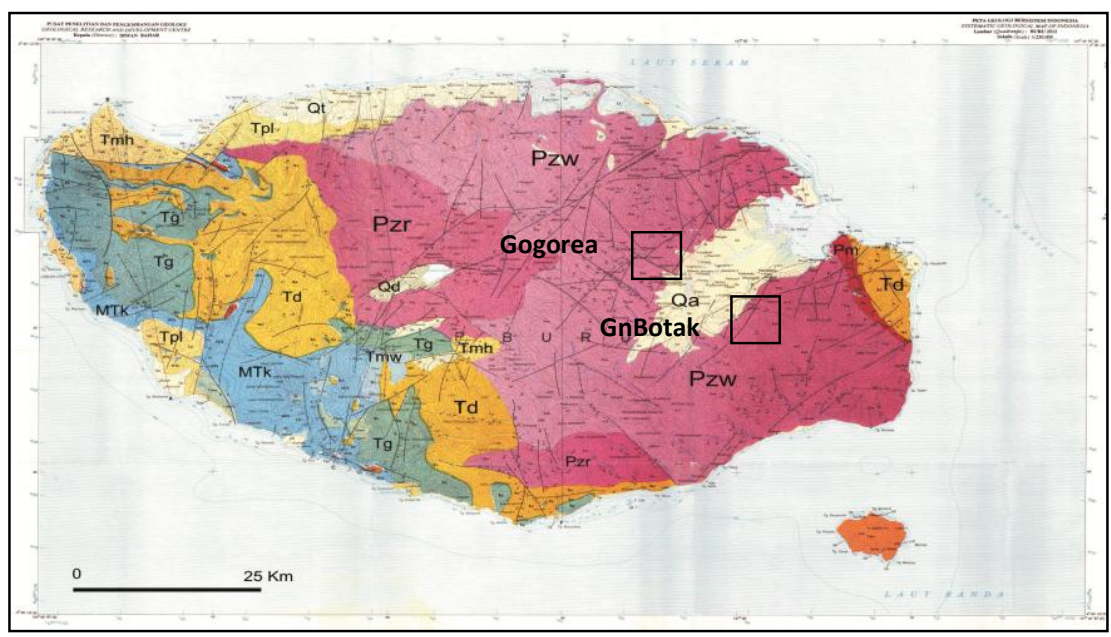

Fig. 3 Geological map of Buru Island (Tjokrosapoetro et al., 1993). Gunung Botak and Gogorea are occupied by Pzw (Wahlua metamorphic rock complex). 


\section{Buru Island gold deposit}

Similar to those of Bombana gold veins, gold mineralization in Buru Island is also hosted by mica schist of Carboniferrous to Permian Wahlua Metamorphic Complex (Pzw) (Fig.3). Hence, it is important to note that the rock characteristics and the ages of both Pzw and Mtpm are exactly the same. Petrographic study exhibits that mica schist in Buru Island is composed of muscovite, chlorite and sericite suggesting of a green schist facies (cf.Yardley, 1989). Gold mineralization in Buru occurred in form of quartz veins/veinlets/reef. Two types/generations of quartz veins are recorded namely (1) Quartz veins which are segmented, sigmoidal, discontinuous and parallel to the foliation of the metamorphic rocks. The vein distribution and pattern is intimately controlled by foliation orientation in the area. Mineralogically, the quartz vein is lack of sulfides, weak mineralized, crystalline, relatively clear and gold may be poor;

(2) Quartz veins occurred within a 'mineralized zone' of about $100 \mathrm{~m}$ in width and $\sim 1,000 \mathrm{~m}$ in length. Gold mineralization is strongly overprinted with argillic alteration zone. Although it is still lack of field data, the mineralization-alteration zone is probably parallel to the mica schist foliation. According to field data and Buru geological map (cf. Tjokrosapoetro et al., 1993), it is interpreted that gold mineralization may be strongly controlled by $\mathrm{N}-\mathrm{S}$ or NE-SW-trending geological structures (strike-slip faults?). Artisanal and small scale gold mining (ASGM) activities are currently concentrated along the structural-controlled mineralization zone.

\subsection{Gold-bearing Quartz Veins}

\section{Bombana}

At least there are three generations of the quartz veins identified. The first generation of quartz vein is parallel to the foliation of mica schist, phyllite and metasediment with general orientation of $\mathrm{N}$ 300oE/60o (Fig. 4a). It was occasionally observed that this first generation of quartz vein is crosscut by quartz veinlets/stockwork/stringers. The second quartz vein generation crosscut the first-generation quartz veins and as well as the foliation of hostrocks (Fig. 4b); whereas the third vein generation is characterized by deformed laminated quartz+calcite vein, which is interpreted as the latest stage of vein formation in the studied area (Fig. 4c). The first generation of quartz veins (that are parallel to foliation) are commonly $2 \mathrm{~cm}$ to $2 \mathrm{~m}$ in width, whereas the second phase quartz veins have commonly less than $10 \mathrm{~cm}$ in width. The thirdgeneration quartz veins hosted by metasediment are mostly parallel to the 'laminated' structures, identified in zones up to 15 meters wide. The first generations of quartz veins are mostly massive to crystalline, occasionally brecciated and sigmoidal, whereas the second quartz veins are narrower than the first and relatively brecciated. In addition, as observed by Prihatmoko et al. (2010), druzy/sugary and some pseudomorph bladed carbonate textures have also been recognized associated with quartz veins/reefs cross cutting foliation. In the Onggomate hill the veins formed a breccias zone composed of quartz as matrix, massive to crystalline, crackle to mosaic, with mica schist and phyllite fragments. In the Roko-Roko hill quartz veins $(1-30 \mathrm{~cm})$ hosted by mica schist and metasediment are commonly massive to crystalline quartz (druzy textures) with pseudomorph bladed carbonate textures. Therefore, at least 2 later stages of veinings (after the first generation veinings) could be identified, including (1) vein breccias and (2) later quartz veinlets, 1-10 $\mathrm{mm}$, which are commonly crystalline and containing native gold (Fig. 4c) (Prihatmoko et al., 2010).
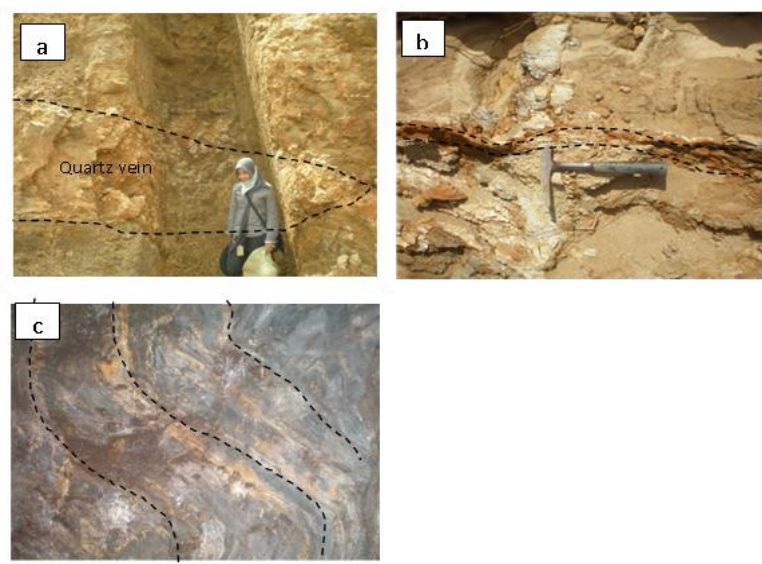

Fig. 4 Gold-bearing orogenic quartz vein characteristics: (a). Brecciated/deformed quartz vein (first generation) which is paralel to the foliation of the mica schist ( $\mathrm{N}$ 300 EE/60\%), (b) highly oxidized / mineralized deformed second quartz vein cross cutting foliation, (c) A cluster of deformed laminated quartz veins hosted by metasediment

\section{Buru Island}

Field and handspecimen observation indicates that gold-bearing quartz veins are characterized by vuggy, banded texture particularly colloform following host rock foliation and sulphide banding (Fig. 5a) and brecciated texture. Bladed-like texture is also observed, but it is rare (Fig. 5b). Those textures are more like developed in classic LS epithermal vein deposits. However, a few anomalies from shallow gold systems in the Yilgarn block of Western Australia are notable. Comb, cockade, crustiform and colloform textures at the Racetrack deposit, Australia, deposited from $\mathrm{CO} 2$-poor fluids in lower greenschist facies rocks are al so recognized (Gebre-Mariam et al., 1993). Similar textures at the Wiluna gold deposits in sub green schist facies rocks, as well as $\delta 180$ quartz measurements as light as 6-7 per $\mathrm{ml}$, provide some of the strongest 
evidence of meteoric water involvement in some of the 'mesothermal' hydrothermal systems (Hagemann et al., 1992, 1994).

Although it is uncommon, but pseudomorph bladed carbonate texture could be present in orogenic quartz veins/reefs if the hydrothermal fluids forming the ore deposit have the right phase separation condition (personal comm.., Richard J. Goldfarb, 2011).
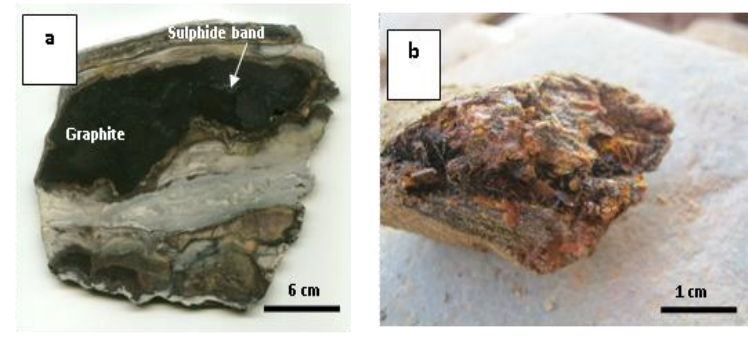

Fig. 5 Hand specimen of quartz vein. (a) Handspecimen of second quartz vein type with banding (colloform texture quartz vein following foliation), graphite and sulphide banding, (b) Handspecimen of highly oxidized/limonitic quartz vein with bladed-like texture indicating a boiling condition (?).

\subsection{Alteration and Ore Mineralogy}

\section{Bombana}

The wallrocks (metamorphic rocks) are strongly weathered, so it is very rare to observe good outcrops in the area. Trenching program by the company along the spurs of Wumbubangka metamorphic mountain range has opened up the soil cover, and exposed clearly the presence of quartz veins and hydrothermally altered rocks. The hydrothermal alteration types recognized in the field includes silicification, clay-sericite \pm silica (argillic), carbonate alteration and carbonization. Silicification is represented by silicified metasediment and mica schist, whereas claysericite \pm silica (argillic) is mostly present surrounding quartz veins or along structural zones. Prihatmoko et al. (2010) also reported the presence of narrow clay-sericite alteration halo (tens $\mathrm{cm}$ to 1 $\mathrm{m})$ around the quartz veins in the Roko-Roko hill. Carbonate alteration is typified by the presence of calcite veinlets/stringers, while carbonization is represented by rare occurrences of graphite/carbon with common black color in the quartz vein/adjacent to the altered wall rocks. The carbonization is considered to be one of the alteration type characteristics, associated with orogenic/metamorphic-hosted gold deposit. Quartz veins/reefs/veinlets contain very small amount of sulphide minerals (up to $5 \%$. Pyrite, chalcopyrite, cinnabar (HgS), stibnite (Sb2S3), tripuhyite (FeSbO4) and rare arsenopyrite (FeAsS2) are present in the quartz veins and silicified metamorphic wallrocks. Cinnabar is typically pinkish red in color and present abundantly in both primary mineralization and in placer gold deposit.
On the other hand, in the primary mineralization, cinnabar commonly occurred in the form of mineralized layers along foliations of the metamorphic rocks (Fig. 6a). Stibnite and tripuhyite seem to be filling fractures parallel to foliations (Fig. $6 \mathrm{~b})$ and disseminated within the silicified wall rocks. In general, gold is very fine-grain, but occasionally native gold is visible in quartz veins (Fig. 6c,d). Cinnabar and stibnite are genetically closely related to gold mineralization. Those sulfides could be pathfinder minerals for the exploration of the metamorphic-hosted gold deposit. AAS ore chemistry indicates a very broad and erratic variation of gold grade ranging from below detection limit $(0.005 \mathrm{~g} / \mathrm{t}$ ) to $84 \mathrm{~g} / \mathrm{t} \mathrm{Au}$ (based on present study and Prihatmoko et al. (2010)), even a single analysis of quartz vein sample (BVAL01) from the Valentino cave (a natural cave) in Wumbubangka at the northern part of the Rumbia mountain shows a high Au grade of $134 \mathrm{~g} / \mathrm{t}$. Few of the typical pathfinder minerals associated with orogenic/metamorphic-hosted gold deposit are stibnite and tripuhyite. The chemical composition of the minerals analyzed using EPMA (Electron Probe Micro Analyzer) indicates that both antimony-bearing minerals (stibnite and tripuhyite) contain a significant amount of As of up to $1 \mathrm{wt} . \%$
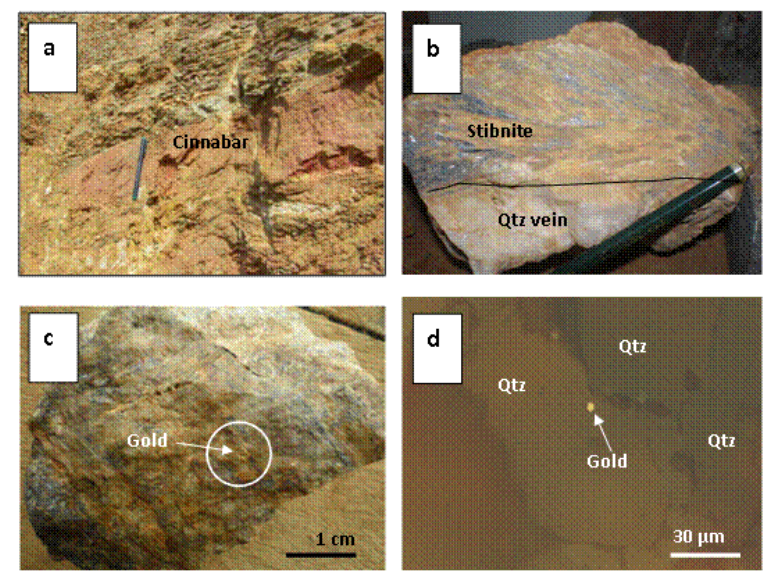

Fig. 6 Diagnostic sulfides associated with Bombana orogenic gold mineralization: (a). Layer-like pinkish cinnabar paralel to mica schist foliation, (b). Fibrous stibnite mainly parallel to the foliations, (c). Visible native gold in multiple quartz veins, and (d). Fotomicrograph of free gold in quartz vein.

\section{Buru Island}

As outlined above, gold mineralization zone is intimately associated with argillic-altered mica schist delineating an obvious high Au grade zone of about $100 \mathrm{~m}$ width and 1,000 m length. Clay mineral types characterizing argillic alteration zone are unknown. Petrographic analysis shows host rock is also propyllitically altered typified by the presence of chlorite, calcite and sericite. Carbonation alteration style represented by graphite banding and carbon flakes is a typical alteration type occurred in metamorphic-related hydrothermal ore deposits. Ore mineralization is 
characterized by pyrite, native gold, pyrrhotite and arsenopyrite. As found in Bombana, cinnabar and stibnite are also identified in association with gold. In general, sulphide minerals are rare $(<3 \%$. This is consistent with mineralogical features of other metamorphic rock-hosted gold mineralizations worldwide (cf. Groves et al., 1998, 2003).

\subsection{Ore Mineralizing Fluids}

\section{Bombana}

A total of 6 quartz veins/reefs from three different generations were prepared for fluid inclusion analysis. This study has enabled to understand the characteristics including temperature, salinity and composition of mineralizing hydrothermal fluids that formed the three generations of quartz veins.The data show that Tm of fluid inclusions hosted by first generation of quartz veins (that are parallel to the foliation) tend to be lower ranging from -2.3 to $-10 \stackrel{\circ}{ } \mathrm{C}$ (mean -3.2 to $-5.9 \stackrel{\circ}{\circ}$ ) corresponding to relatively higher salinity ranging from 5.26 to $9.08 \mathrm{wt} . \% \mathrm{NaCl}$ eq.) in comparison to those of other generations of quartz veins/reefs. The temperature of homogenization (Th), interpreted to bethe formation temperature of the first generation of quartz vein varies from 185 to $245^{\circ} \mathrm{C}$, that are relatively higher than those of other two generations of quartz veins/reefs.The second generation of quartz veins, that cross-cut foliation and have generally higher gold content, is formed in moderate temperatures of 132-283 $9 \mathrm{C}$ (mean 158-209 $\mathrm{O}$ C) and salinity of 3.55-5.86 wt.\% $\mathrm{NCl}$ eq. The latest generation stage of veining represented by quartz+calcite laminated veins was originated at the lowest temperature of 114-176 $\circ \mathrm{C}$ and salinity of $0.35-4.03 \mathrm{wt} . \% \mathrm{NaCl}$ eq. Fig. 7 displays the plotting between Th and salinity of fluid inclusions from all quartz vein generations. It is clearly indicatived that the first quartz vein generation underwent "an isothermal mixing with fluids with contrasting salinity", and is interpreted that the first quartz generation is dominantly originated from hydrothermal magmatic fluid mixing with metamorphic fluids. During the mixing, the temperature change is minor or relatively isothermal, but the salinity decreases significantly. The second and third quartz vein generations are likely formed from mixing of the magmatic and metamorphic fluids, and with cooler less saline meteoric water. This is shown by a systematic decrease of temperature and salinity (Fig. 7). The evidences of the contribution of metamorphic fluid, hydrothermal magmatic fluids and meteoric water that formed the quartz veins are represented by $\mathrm{H} 2 \mathrm{O}-\mathrm{NaCl}-\mathrm{CO} 2$ fluid inclusions (Fig. $8 a, b)$. Petrographically the carbonic fluid inclusions are occasionally observed and may contain small portion of $\mathrm{CO} 2$, probably max. $4 \% \mathrm{CO} 2$ (personal comm., Richard J. Goldfarb, 2011). Raman spectrometric analysis confirms the presence of dissolved carbon dioxide (CO2) in primary fluid inclusion with a certainty of up to $92.73 \%$ ((Fig. 8c).).

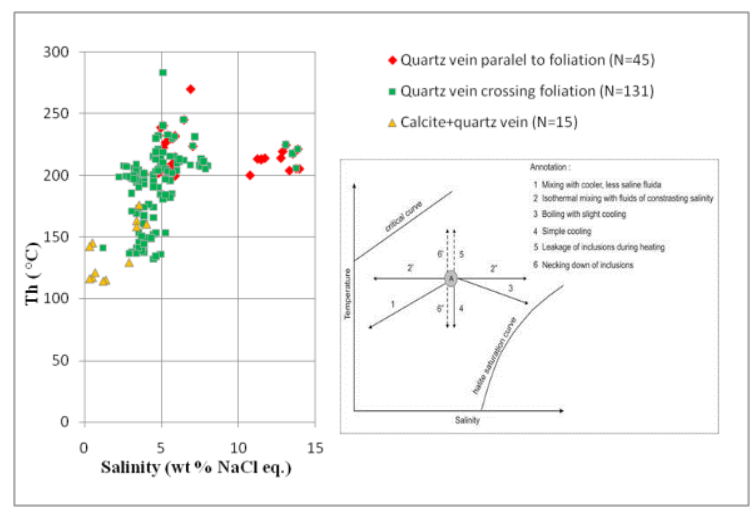

Fig. 7. Temperature of homogenization (Th) vs salinity of fluid inclusions from three different quartz vein generations at Bombana metamorphic-hosted gold deposit. The hydrothermal fluid evolution of the three types of quartz veins are also shown and discussed in the text. Schematic model of fluid evolution is adapted from Shepherd et al. (1985).
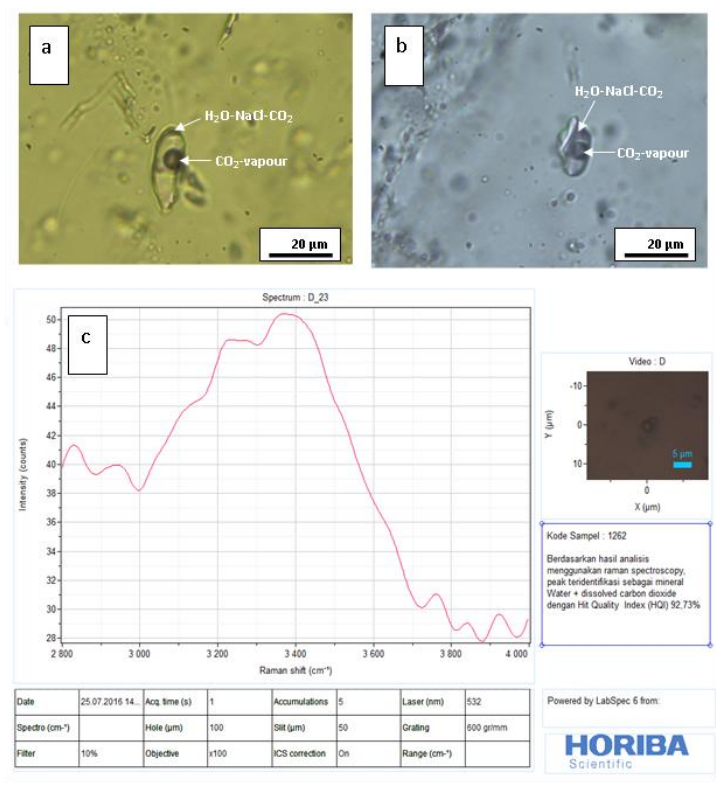

Fig. 8 Fluid inclusion study: (a) and (b). CO2-rich L-V fluid inclusions hosted by quartz veins, and (c). Raman spectrometric analysis of carbonic fluid inclusion containing dissolved $\mathrm{CO} 2$ with certainty up to $92.73 \%$

\section{Buru Island}

A total of 5 quartz veins/reefs from two different types were analysed for fluidinclusion study. Four samples contain measurable fluid inclusions, and those of one sample (B05VA) are too small to be measured.The data in Table 1show that Tm of fluid inclusions hosted by first type of quartz veins (that are crystalline, clear, weak mineralized and parallel to the foliation) tend to have Tm ranging from - 0.1 to $-0.3{ }^{\circ} \mathrm{C}$ (average $-0.22{ }^{\circ} \mathrm{C}$ ) corresponding to salinity ranging from 0.18 to 0.53 wt. $\% \mathrm{NaCl}$ eq.(average 0.36 wt.\% $\mathrm{NaCl}$ eq.), relatively lower than those of second quartz vein type ( $\mathrm{Tm}=-0.2$ to $-0.3{ }^{\circ} \mathrm{C}$; average $-0.27{ }^{\circ} \mathrm{C}$ ) which correspond to salinities of 0.36 to $0.54 \mathrm{wt} \% \mathrm{NaCl}$ eq., averaging 0.48 wt.\% $\mathrm{NaCl}$ eq. The temperature of 
homogenization (Th), interpreted to be the formation temperature of the first type of quartz vein varies from 234 to $354{ }^{\circ} \mathrm{C}$, that are relatively lower than those of second quartz veins type (Th = 321 to $400^{\circ} \mathrm{C}$ ). Petrographic study indicates that fluid inclusions in both quartz vein types consist of 4 phases including L-rich, V-rich, L-V-rich and L1L2-V (CO2)-rich phases. In addtion, Sample B05VB is characterized by abundant $\mathrm{V}$-rich and L-rich inclusions which may imply a boiling condition with an elevated temperature of $400 \stackrel{\circ}{\circ}$. In fact, this sample was taken from Gunung Botak where the artisanal and smal-scale mining (ASGM) situated. Crush-leach analysis of fluid inclusions from Bombana and Buru Island gold veins suggests that the halogen fluid chemistry $(\mathrm{Br} / \mathrm{Cl}$ vs $/ \mathrm{Cl}$ plot) is not identical to magmatic or epithermal related fluids, but tends to be similar to fluids in mesothermaltype gold deposits (Fig. 9).

Tabel 1. Microtermometric data of fluid inclusions within quartz veins associated with gold mineralization in Buru Island

\begin{tabular}{|c|c|c|c|c|c|c|}
\hline No. & Sample code & Vein type & $\mathbf{M}$ & Im & Th & Salinity \\
\hline \multirow[t]{9}{*}{1} & B01 V & First & 1 & -0.2 & 234.7 & 0.36 \\
\hline & & & 2 & -0.2 & 3428 & 0.36 \\
\hline & & & 3 & -0.2 & 239 & 0.36 \\
\hline & & & 4 & -0.2 & 323.7 & 0.36 \\
\hline & & & 5 & -0.1 & 354 & 0.18 \\
\hline & & & 6 & -0.2 & 325.6 & 0.36 \\
\hline & & & 7 & -0.3 & 338.1 & 0.53 \\
\hline & & & 8 & -0.2 & 350 & 0.36 \\
\hline & & & 9 & -0.2 & 300 & 0.36 \\
\hline \multirow[t]{6}{*}{2} & GK 01 & First & 1 & -0.3 & 319.5 & 0.53 \\
\hline & & & 2 & -0.3 & 3227 & 0.53 \\
\hline & & & 3 & -0.2 & 285 & 0.36 \\
\hline & & & 4 & -0.2 & 278 & 0.36 \\
\hline & & & 5 & -0.3 & 308.6 & 0.53 \\
\hline & & & 6 & -0.2 & 281.4 & 0.36 \\
\hline \multirow[t]{8}{*}{3} & B05 V(B) & Second & 1 & -0.3 & 354 & 0.53 \\
\hline & & & 2 & -0.3 & 348 & 0.53 \\
\hline & & & 3 & -0.2 & 389 & 0.36 \\
\hline & & & 4 & -0.2 & 400 & 0.36 \\
\hline & & & 5 & -0.3 & 400 & 0.53 \\
\hline & & & 6 & -0.3 & 400 & 0.53 \\
\hline & & & 7 & -0.3 & 400 & 0.53 \\
\hline & & & 8 & -0.3 & 400 & 0.53 \\
\hline \multirow[t]{14}{*}{4} & GB 01 & Second & 1 & -0.3 & 398 & 0.53 \\
\hline & & & 2 & -0.2 & 384 & 0.36 \\
\hline & & & 3 & -0.3 & 372 & 0.53 \\
\hline & & & 4 & -0.3 & 398 & 0.53 \\
\hline & & & 5 & -0.3 & 400 & 0.53 \\
\hline & & & 6 & -0.2 & 331.8 & 0.36 \\
\hline & & & 7 & -0.3 & 387 & 0.53 \\
\hline & & & 8 & -0.2 & 349.7 & 0.36 \\
\hline & & & 9 & -0.3 & 400 & 0.53 \\
\hline & & & 10 & -0.2 & 325.8 & 0.36 \\
\hline & & & 11 & -0.2 & 3325 & 0.36 \\
\hline & & & 12 & -0.3 & 361.2 & 0.53 \\
\hline & & & 13 & -0.3 & 349.7 & 0.53 \\
\hline & & & 14 & -0.3 & 321.3 & 0.53 \\
\hline
\end{tabular}

$\mathrm{M}=$ measurement number, $\mathrm{Tm}=$ Temperature of melting $\left({ }^{\circ} \mathrm{C}\right)$

$\mathrm{Th}=$ Temperature of homogenization $\left({ }^{\circ} \mathrm{C}\right)$ and salinity $(\mathrm{w}$.\% $\% \mathrm{NaCl}$ eq.).

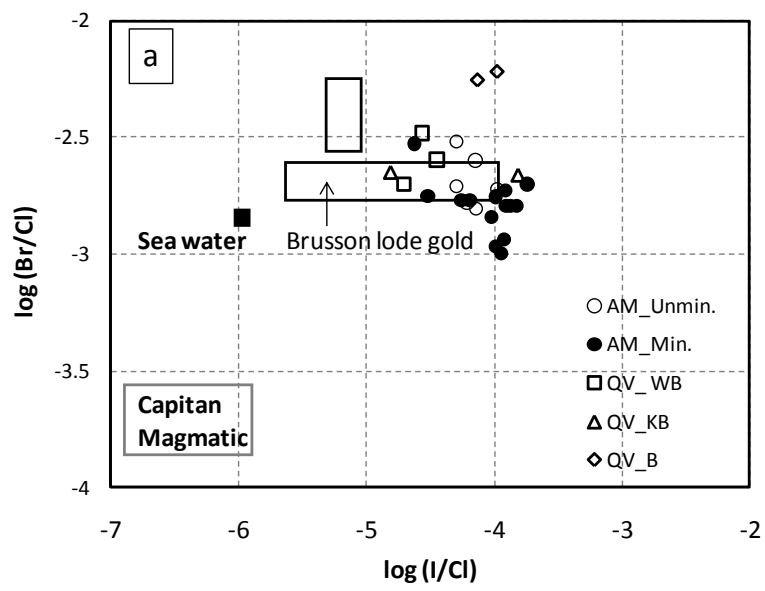

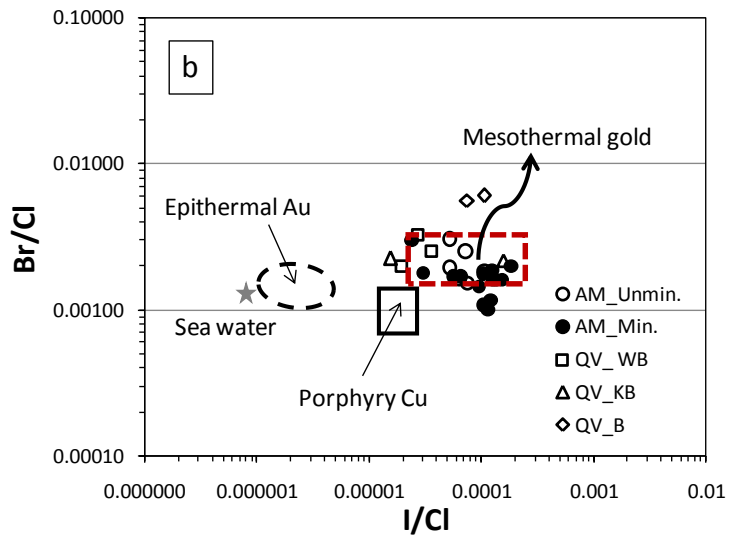

Fig. 9 Crush-leach analysis of halogen content $(\mathrm{I} / \mathrm{Cl}$ and $\mathrm{Br} / \mathrm{Cl}$ ratios) in fluid inclusion showing mineralizing fluids are not identical to magmatic fluid (a), epithermal (meteoric water-dominated) and porphyry $\mathrm{Cu}$ (b), but tends to be similar to fluids in mesothermal-type gold deposits.

\section{Conclusions and Significances for Exploration}

\subsection{Conclusions}

Briefly concluded that primary gold mineralization in Bombana particularly in Wumbubangka area, at the northern flank of the Rumbia mountain range is predominantly hosted by mica schist which is petrologically categorized into greenschist facies. This type of metamorphic facies mostly hosts the orogenic gold deposits worldwide, e.g. Mt. Charlotte, Lancefield and Golden Mile (Gebre-Mariam et al., 1995; Goldfarb, 2009). The presence of pathfinder minerals such as cinnabar, stibnite and tripuhyite genetically indicates that the orogenic gold deposit in the Bombana is emplaced into transition between epizonal and mesozonal referred to the conceptual model of orogenic gold deposit (cf. Groves et al., 1998, 2003) (Fig. 10). It implies that the mineralization may be formed at approximately $5 \mathrm{~km}$ depth below paleosurface. In addition, the observable characteristics of goldbearing quartz veins/veinlets have met with the criteria of orogenic gold type, i.e. sheared/deformed, segmented, brecciated and occasionally sigmoidal, which are the key indications for brittle condition of the epizonal-mesozonal transition. The quartz veins/reefs are commonly characterized by massive and crystalline textures. However, druzy and pseudomorph bladed carbonate textures are also occasionally recognized. Although it is uncommon, but bladed carbonate could be present in orogenic quartz veins/reefs if the hydrothermal fluids forming the deposit have the right phase separation situation (personal comm., Richard J. Goldfarb, 2011).Ore mineralizing fluid is characterized by moderate to low salinity ranging from 5.26 to 9.08 wt.\% $\mathrm{NaCl}$ eq., 3.55-5.86 wt.\%NCl eq. and 0.35-4.03 wt.\% $\mathrm{NaCl}$ eq. as well as moderate to low temperature of homogenization (Th) varying from 185 to $245^{\circ} \mathrm{C}, 132$ to $283^{\circ} \mathrm{C}$, and 114 to $176^{\circ} \mathrm{C}$ for first, second and third generation veins, respectively. 


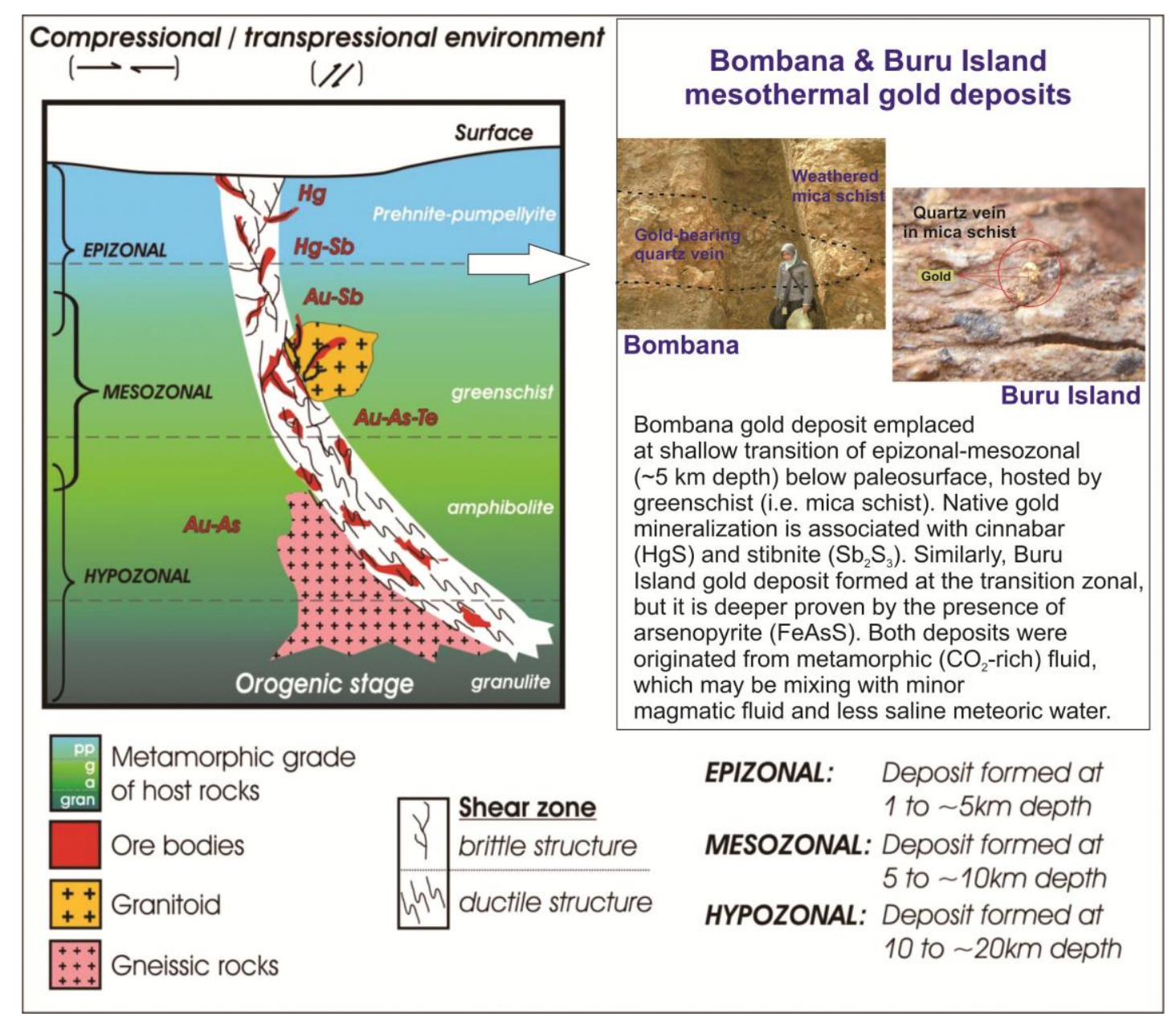

Fig. 10. The Bombana and Buru Island metamorphic-hosted gold deposit plotted on the conceptual orogenic gold deposit model from Groves et al. $(1998,2003)$ emplaced into shallow level at the transition between epizonal and mesozonal (approximately $5 \mathrm{~km}$ below paleosurface).

CO2-rich fluid inclusion is present in small portion, but its presence is well confirmed by Raman spectrometric data. Crush-leach analysis of fluid inclusion shows that mineralizing fluid characteristics are not identical to both epithermal (meteoric water-dominated) and magmatic fluids, but tends to fit with the properties of mesothermal related fluids. Similarly, Buru Island gold mineralization is hosted by mica schist, which is composed of muscovite, chlorite and sericite, thus this metamorphic rock is grouped into green schist facies. Two generations of gold-bearing quartz veins are identified. First quartz veins are typically segmented, sigmoidal, discontinuous and parallel to the foliation of the metamorphic rocks. Second quartz veins occurred within a 'mineralized zone' of about $100 \mathrm{~m}$ in width and $-1,000 \mathrm{~m}$ in length. The mineralized quartz vein is probably parallel to the mica schist foliation. Mineralized zone is generally brecciated and overprinting with argillic alteration zone with N-S or NE-SW orientation. Mineralized zone may strongly be controlled by N-S or NE-SWtrending strike-slip faults. Second quartz vein texture is characterized by brecciated, banding texture such as colloform following foliation, sulphide banding and occasionally bladed-like texture. Host rock is altered to propylitic, argillic, silicification and carbonation. Carbonation is shown by graphite banding and carbon flakes associated with quartz banding. Typically, sulphide minerals are rare $(<3 \%$. Cinnabar, stibnite, arsenopyrite, pyrite and native gold are identified, those mineral are indicative of mineralization systems of orogenic gold. Assay results indicate that 11 of 15 samples yielded more than $1 \mathrm{~g} / \mathrm{t} \mathrm{Au}$, in which 6 of them are in excess of $3 \mathrm{~g} / \mathrm{t} \mathrm{Au}$. It can be noted that all highgrade samples are originally or containing limonitic materials, that suggest the role of supergene enrichment. Interestingly, most of the high-grade samples contain al so high grade As (up to 991ppm), $\mathrm{Sb}$ (up to $885 \mathrm{ppm}$ ), and $\mathrm{Hg}$ (up to $75 \mathrm{ppm}$ ). Hydrothermal fluid is typified by $\mathrm{CO} 2$-rich fluid, moderate temperature of $300-400^{\circ} \mathrm{C}$ ('mesothermal T range') and a typical low salinity ( 0.36 to $0.54 \mathrm{wt} . \%$ $\mathrm{NaCl}$ eq), which suggests that the metamorphic fluid is responsible for the formation of the Buru gold deposit. 


\subsection{Significance for Gold Exploration}

Although gold mineralization both in Bombana and Buru Island has some discrepancies, but by considering all key features discussed above, the primary metamorphic-hosted gold mineralization type tends to meet the criteria of 'orogenic gold type' (cf. Groves et al., 1998; 2003), rather than epithermal or other hydrothermal deposit types. Therefore, the discovery of the metamorphichosted gold deposit in the Rumbia metamorphic mountain range, Buru Island (Gunung Botak and Gogorea prospects) and its vicinity has opened up more targets and challenges for gold exploration in the region, and other terrains in Indonesia particularly Eastern Indonesia that have identical geological setting. It is also important to note that all high-grade samples are originally or containing limonitic/oxidized materials, that suggest the role of supergene enrichment. A further study on other genetic parameters of the deposit such as ratios of detailed mineralogy (sulfides \& gangue), base metals, pathfinder elements, specific features, etc is needed for a better understanding of the genesis of the Bombana and Buru Island gold deposits.

\section{Acknowledgements}

The authors wish to express a gratitude to the Directorate of Higher Education, Department of National Education, Indonesia, for "International Competitive Grant" 2009 with contract number of 694/SP2H/PP/DP2M/X/2009 granted to the first author as a principal researcher. We are also indebted to the Energy and Mineral Resources Agency of Southeast Sulawesi and Bombana Regency, respectively for their permission. The supports and permission from Management of PT. Panca Logam Makmur are much acknowledged. Some field data/ report provided by PT. AGC Indonesia are acknowledged. This study is also made possible through financial support from Barry Smith and Research Cooperation Program 2013 between the first author with Geological Resources Research Center (PSDG) Bandung. Prof. Victor Okrugin (Kamchatka University, Russia) provided an ICP-MS single analysis. Crush-leach analysis of fluid inclusion was done in Leoben University, Austria. Those supports are highly acknowledged. Fadlin Idrus and Satriadin Abdullah are thankful for their fieldwork assistances and data processing.

\section{References}

Gebre-Mariam, M., Hagemann, S. G., and Groves, D. I., 1995, A classification scheme for epigenetic Archaean lode-gold deposits. Mineralium Deposita 30: 408-410.

Groves, D. I., Goldfarb, R. J., Gebre-Mariam, M., Hagemann, S. G. and Robert, F., 1998, Orogenic gold deposit: A proposed classification in the context or their crustal distribution and relationship to other gold deposit types. Ore Geology Review 13: 7-27.
Groves, D. I., Goldfarb, R. J., and Robert, F., 2003, Gold deposit in metamorphic belts: Overview or current understanding, outstanding problems, future research, and exploration significance. Economic Geology 98: 1-29.

Hagemann, S.G., Groves, D.I., Ridley, J.R., Vearncome, J.R., 1992. The Archaean lode-gold deposits at Wiluna, Western Australia. High level brittle-style mineralisation in a strike-slip regime. Econ. Geol. 87, 1022-1053.

Hagemann, S.G., Gebre-Mariam, M., Groves, D.L., 1994. Surface-water influx in shallow-level Archean lode-gold deposits in Western Australia. Geology 22, 1067-1070.

Idrus, A., Mansur, S., Ahmad, Rahmayuddin \& Mahdi, A., 2016, Occurrences and Characteristics of Gold Mineralization in Rampi Block Prospect, North Luwu Regency, South Sulawesi Province, Indonesia, Jounal of Applied Geology, Volume 8, January-June 2016 Edition, accepted.

Prihatmoko, S., Lubis, H., Hernawan, S., 2010, Evaluation report of Bombana gold prospects, Southeast Sulawesi, unpublished report, PT. AGC Indonesia, 41p.

Querubin, C.D., Walters, S., 2011, Geology and Mineralization of Awak Mas: A Sedimentary Hosted Gold Deposit, South Sulawesi, Indonesia, Proceedings of The Sulawesi Mineral Seminar, Manado 28-29 November 2011, p. 211-229.

Simandjuntak, T.O., Surono, Sukido, 1993, Peta geologi lembar Kolaka, Sulawesi, P3G, Bandung.

Shepherd, T.J., Rankin, A.H., Alderton, D.H.M., 1985, A practical guide to fluid inclusion, Blackie, London, 239p.

Tjokrosapoetra, S., Budhitresna, T., Rusmana, E., 1993, Peta Geologi Lembar Buru, Maluku, Pusat Penelitian and Pengembangan Geologi (P3G), Bandung.

Wajdi, M.F., Santoso, S.T.J., Kusumanto, D., Digdowirogo, S., 2011, Metamorphic Hosted Low Sulphidation Epithermal Gold System at Poboya, Central Sulawesi: A General Descriptive Review, Proceedings of The Sulawesi Mineral Seminar, Manado 28-29 November 2011, p. 201210.

Yardley, B. W. D., 1989, An introduction to metamorphic petrology. Longman Scientific \& Technical, Essex, 247p. 